\section{Effects of substrate type on plant growth and nitrogen and nitrate concentration in spinach}

\author{
Carina Barcelos, ${ }^{1}$ Rui M.A. Machado, \\ Isabel Alves-Pereira, ${ }^{2}$ Rui Ferreira, ${ }^{2}$ \\ David R. Bryla ${ }^{3}$
}

${ }^{1}$ Department of Fitotecnia; ${ }^{2}$ Department of Chemistry, University of Évora, Portugal; ${ }^{3}$ USDA-ARS, Horticultural Crops Research Unit, Corvallis, OR, USA

\begin{abstract}
The effects of three commercial substrates (a mixture of forest residues, composted grape husks, and white peat, black peat and coir) on plant growth and nitrogen $(\mathrm{N})$ and nitrate $\left(\mathrm{NO}_{3}\right)$ concentration and content were evaluated in spinach (Spinacia oleracea L. cv. Tapir). Spinach seedlings were transplanted at 45 days after emergence into Styrofoam boxes filled with the substrates and were grown during winter and early spring in an unheated greenhouse with no supplemental lighting. Each planting box was irrigated daily by drip and fertilized with a complete nutrient solution. The $\mathrm{NO}_{3}$ content of the drainage water was lower in coir than in the other substrates. However, shoot $\mathrm{NO}_{3}$ concentration was not affected by substrate type, while yield and total shoot $\mathrm{N}$ and $\mathrm{NO}_{3}$ content were greater when plants were grown in peat than in the mixed substrate or the coir. Leaf chlorophyll meter readings provided a good indication of the amount of $\mathrm{N}$ in the plants and increased linearly with total shoot $\mathrm{N}$.
\end{abstract}

\section{Introduction}

The use of substrates and soilless culture systems for production of horticultural crops is increasing worldwide. Substrates often increase plant growth and yield in many crops, reduce the incidence of soil-borne diseases, and, when combined with collection of drainage water, increase the efficiency of water and nutrient use. ${ }^{1-4}$ Despite these many benefits, there is currently very little information available concerning the influence of substrate type on plant growth and nutrient uptake in many crops, including leafy vegetables. Physical and chemical properties such as bulk density, water holding capacity, $\mathrm{pH}$, cation exchange capacity, and nutrient content vary considerably among substrates and, therefore, likely have a considerable influence on plant development and nutrition.
Tissue nitrate $\left(\mathrm{NO}_{3}\right)$ concentrations tend to be higher when plants are grown in soilless culture systems, ${ }^{5,6}$ and leafy vegetables such as spinach can accumulate levels that may be harmful to human health. ${ }^{7,8}$ In many cases, the concentration of $\mathrm{NO}_{3}$ in the plant tissues increases due to low light conditions and reduced photoperiod in these systems. ${ }^{9-13}$ For example, a reduction of light from 800 to 200 mol $\times \mathrm{m}^{-2} \times \mathrm{s}^{-1}$ increased total shoot $\mathrm{NO}_{3}$ concentration in spinach by more than $200 \%{ }^{14}$ Nitrate accumulation also varies with the season, where it is often higher during the autumn and winter months than during the spring and summer. ${ }^{15-17}$

The objective of this study was to evaluate the influence of different substrate types on plant growth and shoot nitrogen $(\mathrm{N})$ and $\mathrm{NO}_{3}$ concentrations of spinach grown in an unheated greenhouse during the winter and early spring.

\section{Materials and Methods}

\section{Growth conditions and substrates}

The experiment was conducted in a greenhouse located at the Herdade Experimental $d a$ Mitra (38 $\left.3152 \mathrm{~N} ; 8^{\circ} 0105 \mathrm{~W}\right)$, University of Évora, Portugal. The greenhouse was covered with thermal polyethylene and had no supplemental lighting. Air temperatures inside of the greenhouse ranged from 5 to $26^{\circ} \mathrm{C}$, and solar radiation ranged from 34 to $248 \mathrm{~W} \cdot \mathrm{m}^{-2} \cdot \mathrm{d}^{-1}$. The experiment comprised three different commercial substrates: a mixture of forest residues, composted grape husks, and white peat (Substrato Universal Agriloja); a black peat blend (Super Terra Torfkultursubstrat 1; Hawita Flor, Germany); and a coir blend (Pelemix España S.L., Spain). Physical and chemical characteristics of the substrates, according manufacturer, are shown in Table 1. Mass wetness, moisture content, and bulk density were determined following the methods described by Fonteno and Harden (Table 2). ${ }^{18}$

Spinach (Spinacia oleracea L. cv. Tapir) seedlings were transplanted at 45 days after emergence into to Styrofoam planting boxes (100-cm long $\times 25-\mathrm{cm}$ wide $\times 10-\mathrm{cm}$ high) filled with $16 \mathrm{~L}$ of substrate. The seedlings were spaced 8-cm apart in three rows per box and $10-\mathrm{cm}$ apart between rows. Treatments were arranged in a randomized complete block design with five replicate boxes per substrate treatment.

Each planting box was irrigated using $4 \mathrm{~L} \cdot \mathrm{h}^{-1}$ pressure-compensating drip emitters. Irrigation was controlled by a timer and averaged 20 to $30 \%$ drainage (leaching fraction) at each application. Nutrient solution was applied daily by fertigation, from transplanting
Correspondence: Rui M. A. Machado, Department of Fitotecnia, University of Évora, Mitra, 7000 Évora, Portugal.

Tel.: +351.2667660822 - Fax: +351.2667608828 .

E-mail: rmam@uevora.pt

Key words: Spinacia oleracea; chlorophyll meter; coir; peat; soilless culture systems.

Acknowledgements: we thank Luiseta and Maria das Dores for technical assistance.

Contributions: $\mathrm{CB}$, experimental work, writing the paper; RMAM, experimental plan, writing the paper; IA-P, nitrate chemical analysis and data interpretation; RF, data interpretation; DRB, data presentation and writing the paper.

Conflict of interest: the authors declare no potential conflict of interests.

Funding: Instituto de Ciências Agrárias e Ambientais Mediterrânicas (ICAAM).

Received for publication: 24 November 2015. Revision received: 25 January 2016. Accepted for publication: 25 January 2016.

This work is licensed under a Creative Commons Attribution-NonCommercial 4.0 International License (CC BY-NC 4.0).

(C) Copyright C. Barcelos et al., 2016

Licensee PAGEPress srl, Italy

International Journal of Plant Biology 2016; 7:6325 doi:10.4081/pb.2016.6325

to the day before harvest. The solution was made from fresh tap water [electrical conductivity (EC) of $0.3 \mathrm{dS} \cdot \mathrm{m}^{-1} ; \mathrm{pH} 7$; and $0.10-0.30$ $\mathrm{mmol} \cdot \mathrm{L}^{-1} \mathrm{NO}_{3}$ ] and initially contained 4.78 $\mathrm{mmol} \cdot \mathrm{L}^{-1} \quad \mathrm{NO}_{3}, \quad 1.16 \mathrm{mmol} \cdot \mathrm{L}^{-1} \quad \mathrm{NH}_{4}, \quad 0.43$ $\mathrm{mmol} \cdot \mathrm{L}^{-1} \mathrm{P}, 4.29 \mathrm{mmol} \cdot \mathrm{L}^{-1} \mathrm{~K}, 1.40 \mathrm{mmol} \cdot \mathrm{L}^{-1} \mathrm{Ca}$, $0.49 \mathrm{mmol} \cdot \mathrm{L}^{-1} \mathrm{Mg}, 0.54 \mathrm{mmol} \cdot \mathrm{L}^{-1} \mathrm{~S}, 46 \mu \mathrm{mol} \cdot \mathrm{L}^{-1}$ $\mathrm{B} ; 7.86 \mu \mathrm{mol} \cdot \mathrm{L}^{-1} \mathrm{Cu}, 8.95 \mu \mathrm{mol} \cdot \mathrm{L}^{-1} \mathrm{Fe}, 18.3$ $\mu \mathrm{mol} \cdot \mathrm{L}^{-1} \mathrm{Mn}, 2.60 \mu \mathrm{mol} \cdot \mathrm{L}^{-1} \mathrm{Mo}$, and 7.64 $\mu \mathrm{mol} \cdot \mathrm{L}^{-1} \mathrm{Zn}$. The concentration was adjusted for plant growth at 21 days after transplanting (DAT) to $8.62 \mathrm{mmol} \cdot \mathrm{L}^{-1} \mathrm{NO}_{3}, 1.43 \mathrm{mmol} \cdot \mathrm{L}^{-1}$ $\mathrm{NH}_{4}, 1.70 \mathrm{mmol} \cdot \mathrm{L}^{-1} \mathrm{P}, 4.45 \mathrm{mmol} \cdot \mathrm{L}^{-1} \mathrm{~K}, 1.95$ $\mathrm{mmol} \cdot \mathrm{L}^{-1} \mathrm{Ca}, 0.49 \mathrm{mmol} \cdot \mathrm{L}^{-1} \mathrm{Mg}, 0.54 \mathrm{mmol} \cdot \mathrm{L}^{-1}$ $\mathrm{S}, 46 \mu \mathrm{mol} \cdot \mathrm{L}^{-1} \mathrm{~B}, 7.86 \mu \mathrm{mol} \cdot \mathrm{L}^{-1} \mathrm{Cu}, 8.95$ $\mu \mathrm{mol} \cdot \mathrm{L}^{-1} \mathrm{Fe}, 18.3 \mu \mathrm{mol} \cdot \mathrm{L}^{-1} \mathrm{Mn}, 2.60 \mu \mathrm{mol} \cdot \mathrm{L}^{-1}$ Mo, and $7.64 \mu \mathrm{mol} \cdot \mathrm{L}^{-1} \mathrm{Zn}$. The final pH of both solutions was 5.9.

\section{Measurements}

The $\mathrm{pH}, \mathrm{EC}$, and the concentration of $\mathrm{NO}_{3}$ of the drainage water from each box was measured weekly using a potentiometer ( $\mathrm{pH}$ Micro 2000 Crison), a conductivity meter (LF 330 WTW, Weilhein, Germany), and an ion-specific electrode and meter (Crison Instruments, Barcelona, Spain), respectively, following the 
procedures outlined by Prazeres. ${ }^{19}$ A portable chlorophyll meter (Minolta SPAD-502: Soil Plant Analysis Development, Minolta Co., Osaka, Japan) was used to measure leaf greenness at 24 and 36 DAT. Two recently expanded leaves were selected from three plants in each box for the chlorophyll readings, and three measurements were taken on each leaf on both dates.

The plants were harvested at 36 DAT. The shoots of the plants were cut off at $1 \mathrm{~cm}$ above the substrate surface. Four representative plants (shoots) from each box were washed, oven-dried at $70^{\circ} \mathrm{C}$ for $2-3$ days, weighed, ground, and analyzed for total $\mathrm{N}$ using a combustion analyzer (Leco Corp., St. Joseph, MI, USA). Additional leaf samples were stored at $-80^{\circ} \mathrm{C}$ for $\mathrm{NO}_{3}$ determination. ${ }^{20}$ The samples were oven-dried at $65^{\circ} \mathrm{C}$ for $48 \mathrm{~h}$, weighed $(0.1000 \mathrm{~g})$, macerated in a mortar, homogenized in a test tube with $10 \mathrm{~mL}$ of distilled water, agitated in a vortex, and incubated for 1 $\mathrm{h}$ at $45^{\circ} \mathrm{C}$ in a shaking water bath. Filtrated extract was then mixed with salicylic acid in $5 \%$ sulphuric acid (1:4), incubated for $20 \mathrm{~min}$ at room temperature, and mixed with $9.5 \mathrm{~mL}$ of $2 \mathrm{M}$ sodium hydroxide. The concentration of $\mathrm{NO}_{3}$ in the solution was then determined using UV-VIS spectrophotometer (Thermo Scientific, Genesys 10S) at 338 and $440 \mathrm{~nm}$.

\section{Data analysis}

Data were analyzed by analysis of variance using SPSS Statistics 21 software (Chicago, IL, USA). Means were separated at the $5 \%$ level using Duncan's new multiple range test.

\section{Results and Discussion}

\section{Drainage water}

The $\mathrm{pH}$ in the drainage water was influenced by substrate type (Figure 1A). In gener$\mathrm{al}$, $\mathrm{pH}$ was greater in the drainage water collected from the peat substrate than from the other two substrates. The $\mathrm{pH}$ also increased over time in each treatment, which was likely due to the differential uptake of ions from the nutrient solution. For instance, when $\mathrm{N}$ is supplied in the $\mathrm{NO}_{3}$ form, there is an increase in hydroxide ion $\left(\mathrm{OH}^{-}\right)$concentration in the drainage water. ${ }^{21}$ The nutrient solution used in the present study provided $\approx 80 \%$ of the $\mathrm{N}$ as $\mathrm{NO}_{3}$. On average, the $\mathrm{pH}$ increased at a rate of 0.14 to 0.19 units per week in the three drainage solutions.

The EC and concentration of $\mathrm{NO}_{3}$ in the drainage water were also affected by substrate type (Figure 1B,C). In the former case, $\mathrm{EC}$ was initially greater with coir than with the other two substrates or in the nutrient solution (1.5 $\mathrm{dS} . \mathrm{m}^{-1}$ ). Coir often has high levels of $\mathrm{Na}$ and Cl. ${ }^{1,2,22}$ Coir also resulted in lower $\mathrm{NO}_{3}$ in the drainage water than the other two substrates, which could have been related to lower $\mathrm{N}$ availability in the substrate (Table 1) and to the ability of coconut fiber's to immobilize soluble $\mathrm{N}$ in the mix. ${ }^{23-26}$

Table 1. Physical and chemical characteristics of three commercial substrates.

\begin{tabular}{lccc} 
& Forest residues, husks, and peat & Peat & Coir \\
Organic matter (\%) & 60 & 90 & $94-98$ \\
Organic C (\%) & - & - & $40-50$ \\
\hline Lignin + hemicellulose & - & - & $85-90$ \\
$\mathrm{~N}\left(\mathrm{mg} \cdot \mathrm{L}^{-1}\right)$ & $200-400$ & $50-300$ & - \\
\hline $\mathrm{P}\left(\mathrm{mg} \cdot \mathrm{L}^{-1}\right)$ & $100-200$ & $35-131$ & - \\
$\mathrm{K}\left(\mathrm{mg} \cdot \mathrm{L}^{-1}\right)$ & $150-300$ & $66-332$ & - \\
\hline $\mathrm{pH}$ & $5.5-6.5$ & 6.1 & $5.5-6.5$ \\
$\mathrm{EC}\left(\mathrm{mS} \cdot \mathrm{cm}^{-1}\right)$ & $1-3$ & 0.8 & $<1$ \\
\hline $\mathrm{C} / \mathrm{N} \mathrm{ratio}$ & $<20$ & 53 & 80 \\
\hline
\end{tabular}

Table 2. Mass wetness, moisture content, and bulk density of three commercial substrates.

\begin{tabular}{lccc} 
Substrate & $\begin{array}{c}\text { Mass wetness } \\
(\mathrm{g} \text { water } \times \mathrm{g} \text { substrate) }\end{array}$ & $\begin{array}{c}\text { Moisture } \\
\text { content }(\%)\end{array}$ & $\begin{array}{c}\text { Bullk density } \\
\left(\mathrm{g} \cdot \mathrm{cm}^{-3}\right)\end{array}$ \\
Forest residues, husks, and peat & $2.40^{\mathrm{c}}$ & $70.6^{\mathrm{c}}$ & $0.2^{\mathrm{a}}$ \\
Peat & $7.29^{\mathrm{a}}$ & $87.8^{\mathrm{a}}$ & $0.10^{\mathrm{b}}$ \\
\hline Coir & $4.75^{\mathrm{b}}$ & $82.5^{\mathrm{b}}$ & $0.14^{\mathrm{b}}$ \\
\hline
\end{tabular}

a,b,c Means followed by different letters within a column are significantly different at $\mathrm{P}<0.05$.

Table 3. Effects of three commercial substrates on shoot dry weight and fresh yield of spinach.

\begin{tabular}{lcc} 
Substrate & Shoot dry weight (g/plant) & Yield (kg.m $\left.{ }^{-2}\right)$ \\
Forest residues, husks, and peat & $1.28^{\mathrm{b}}$ & $3.96^{\mathrm{b}}$ \\
Peat & $1.71^{\mathrm{a}}$ & $4.51^{\mathrm{a}}$ \\
\hline Coir & $1.20^{\mathrm{b}}$ & $3.88^{\mathrm{b}}$
\end{tabular}

a,b Means followed by different letters within a column are significantly different at $P \leq 0.05$.

Table 4. Effect of three commercial substrates on leaf chlorophyll (SPAD meter readings) and shoot nitrogen (N) and nitrate (NO $)_{3}$ concentration and content in spinach.

\begin{tabular}{|c|c|c|c|c|c|c|c|}
\hline \multirow[t]{2}{*}{ Substrate } & \multicolumn{2}{|c|}{ Chlorophyll } & \multirow{2}{*}{$\begin{array}{c}\text { Shoot N } \\
\text { concentration } \\
\left(\mathrm{g} \mathrm{kg}^{-1}\right)\end{array}$} & \multirow{2}{*}{$\begin{array}{l}\text { Shoot NO } \\
\left(\mathrm{mg} \mathrm{g}^{-1} \mathrm{DW}\right)\end{array}$} & \multirow{2}{*}{$\begin{array}{l}\text { concentration } \\
\left(\mathrm{mg} \mathrm{g}^{-1} \mathrm{FW}\right)\end{array}$} & \multirow{2}{*}{$\begin{array}{l}\text { Shoot } N \text { content } \\
\text { (mg/plant) }\end{array}$} & \multirow{2}{*}{$\begin{array}{c}\text { Shoot } \mathrm{NO}_{3} \\
\text { content } \\
\text { (mg/plant) }\end{array}$} \\
\hline & $24 \mathrm{DAT}$ & $36 \mathrm{DAT}$ & & & & & \\
\hline $\begin{array}{l}\text { Forest residues, } \\
\text { husks, peat }\end{array}$ & $39.0^{\mathrm{b}}$ & $38.5^{\mathrm{b}}$ & $32.2^{\mathrm{b}}$ & $35.8^{\mathrm{a}}$ & $3.63^{\mathrm{a}}$ & $41.2^{b}$ & $45.7^{\mathrm{b}}$ \\
\hline Peat & $43.1^{\mathrm{a}}$ & $43.8^{\mathrm{a}}$ & $35.9^{\mathrm{a}}$ & $42.3^{\mathrm{a}}$ & $4.57^{\mathrm{a}}$ & $61.4^{\mathrm{a}}$ & $73.9^{\mathrm{a}}$ \\
\hline Coir & $39.0^{\mathrm{b}}$ & $40.1^{\mathrm{b}}$ & $37.9^{\mathrm{a}}$ & $36.8^{\mathrm{a}}$ & $3.83^{\mathrm{a}}$ & $46.0^{\mathrm{b}}$ & $44.1^{\mathrm{b}}$ \\
\hline
\end{tabular}

DAT, days after transplanting; DW, dry weight; FW, fresh weight. a,b Means followed by different letters within a column are significantly different at $\mathrm{P} \leq 0.05$. 


\section{Plant growth and yield}

Plants grown in peat had greater shoot dry weight and more yield (fresh weight) than those grown in other two substrates (Table 3). The yields were similar to those obtained when spinach was grown in a floating system ${ }^{8}$ and greater than those obtained in soil. ${ }^{27,28}$

\section{Leaf chlorophyll and shoot nitrogen and nitrate}

Plants grown in peat were greener and had higher chlorophyll meter readings at 24 and 36 DAT than those grown in the other substrates (Table 4). The readings increased linearly with shoot $\mathrm{N}$ content and were within the range
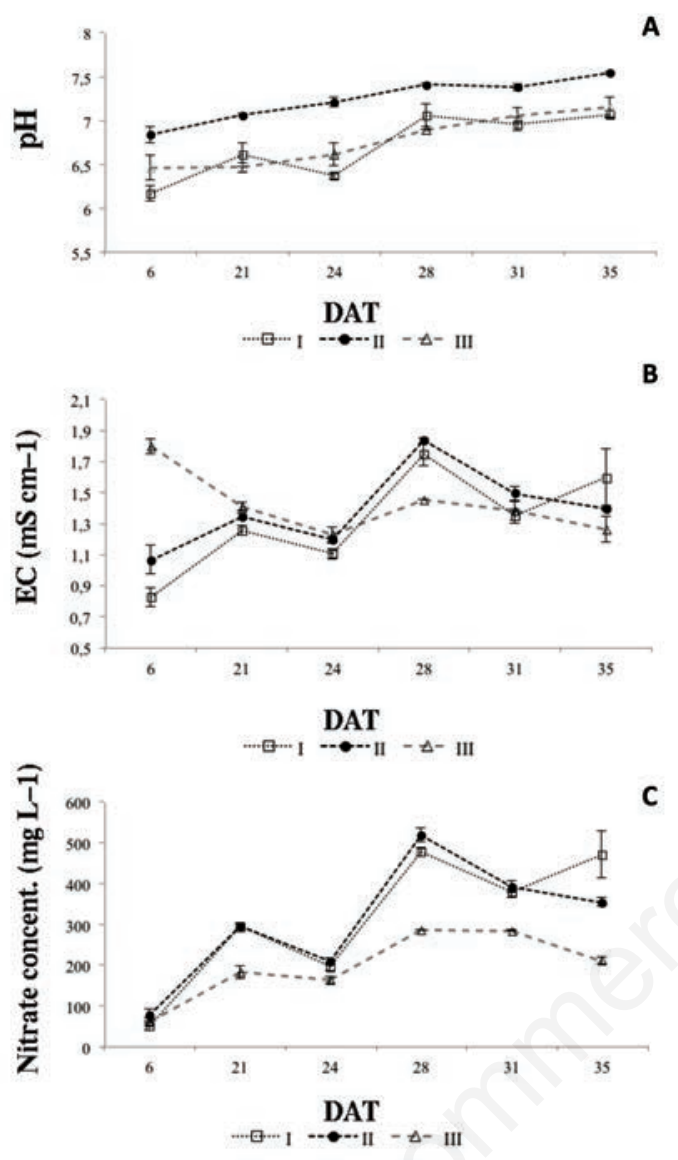

Figure 1. Effects of three commercial substrates (I, forest residues, husks, and peat; II, peat; III, coir) on $\mathrm{pH}(\mathrm{A})$, electrical conductivity $(\mathrm{B})$ and concentration of nitrate $(\mathrm{C})$ in the drainage water. Each symbol represents the mean of four replicates, and the error bars represent \pm 1 standard error.

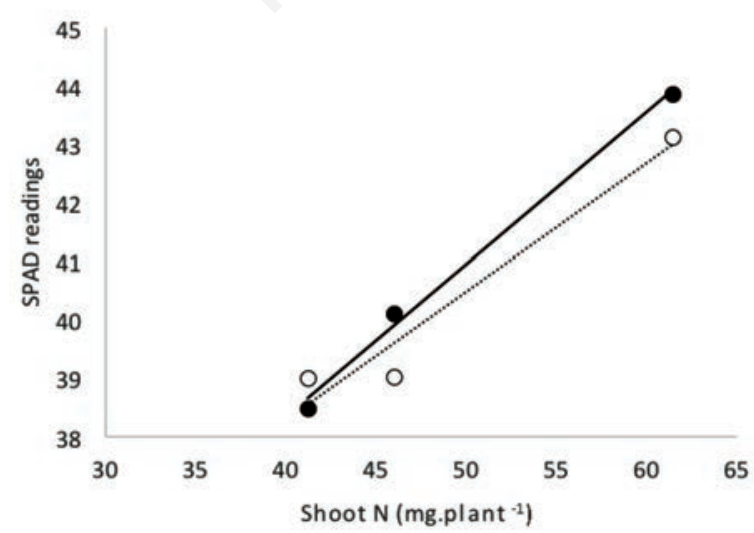

Figure 2. Relationship between shoot $\mathbf{N}(\mathrm{mg} \times$ plant-1) and leaf chlorophyll (SPAD meter readings) at $24(\bigcirc)$ and $36(\bigcirc)$ days after transplanting (DAT) in spinach. SPAD readings $(24 \mathrm{DAT})=0.22 \mathrm{mg} / \mathrm{plant} \mathrm{N}+29.5(\mathrm{r} 2=0.9513, \mathrm{P}<0.0001) ; \mathrm{SPAD}$ readings (36 DÁT $)=0.26 \mathrm{mg} /$ plant $\mathrm{N}+27.9(\mathrm{r} 2=0.9943, \mathrm{P}<0.0001)$. reported by others (Figure 2). ${ }^{8,29,30}$

None of the plants in the treatments showed visual symptoms of $\mathrm{N}$ deficiency. However, plants grown in the mix of forest residues, husks, and peat had lower shoot $\mathrm{N}$ concentration than those grown in the other substrates (Table 4). In general, shoot $\mathrm{N}$ concentrations were higher than those reported in Florida $\left(<30 \mathrm{~g} \mathrm{~kg}^{-1}\right)$ but on the low end of the level considered to be sufficient for spinach at this stage of development (35-55 $\left.\mathrm{g} \mathrm{kg}^{-1}\right) .31,32$

Shoot $\mathrm{NO}_{3}$ concentration was not affected by substrate type (Table 4). In each case, the values were higher than allowed by Regulation (EU) $n^{0} 1258 / 2011$ of the European Commission for fresh spinach $\left(3.5 \mathrm{mg} \mathrm{g}^{-1}\right.$ fresh weight). Therefore, these substrates do not appear to be a means of preventing high shoot $\mathrm{NO}_{3}$ concentrations in spinach. Leaf $\mathrm{NO}_{3}$ concentrations of spinach in a greenhouse, whether grown in soil or soilless culture systems, often exceed the value allowed by the EU. Siomos and colleagues found that plants from a soilless culture system had greater $\mathrm{NO}_{3}$ and total N, P, and $\mathrm{K}$ content than plants harvested from soil. ${ }^{33}$

The high $\mathrm{NO}_{3}$ concentrations in the present study were likely related to the environmental conditions in the greenhouse, nutritional factors, and the cultural techniques used. Light intensity was low in the greenhouse, not only due to the time of year (winter and early spring), but also due to the fact that the plastic film on the greenhouse was not totally transparent, and because a high planting density (64 plants $/ \mathrm{m}^{2}$ ) led to a considerable amount of leaf shading. As previously mentioned, plants often accumulate more $\mathrm{NO}_{3}$ under low light conditions and during reduced photoperiods. ${ }^{9-12}$ Peet and colleagues cited by Gruda found that the amount of daylight received was reduced by $30 \%$ or more by the glasshouse structure, while the other environmental factors, including the availability of water and nutrients, were usually at optimal levels. ${ }^{34}$ The high ratio of $\mathrm{NO}_{3}: \mathrm{NH}_{4}(\approx 80)$ may have also led to high leaf $\mathrm{NO}_{3}$ concentrations in our study. It has been reported that spinach accumulates more $\mathrm{NO}_{3}$ when grown with solutions containing high $\mathrm{NO}_{3}: \mathrm{NH}_{4}$ ratios. ${ }^{8}$ However, in that case, the total amount of $\mathrm{N}$ applied was $12 \mathrm{mmol} \mathrm{L}^{-1}$ and greater used in the present study (5.9 $\mathrm{mmol} \mathrm{L}^{-1}$ from planting to $20 \mathrm{DAT}$ and 10 $\mathrm{mmol} \mathrm{L}^{-1}$ from 21 DAT until the day before harvest).

\section{Conclusions}

Black peat substrate produced more yield and a higher content of $\mathrm{N}$ and $\mathrm{NO}_{3}$ in the shoots than the mix of forest residues, composted grape husks, and white peat or the coir 
substrate. SPAD meter readings provided a good indication of the amount of $\mathrm{N}$ in the plants.

\section{References}

1. Raviv M, Wallach R, Silber A, et al. Substrates and their analysis. In: Savvas D, Passam H, eds. hydroponic production of vegetables and ornamentals. Athens: Embryo Publications; 2002. pp. 25-102.

2. Quintero M, González C, Guzmán J. Sustratos para cultivos hortícolas y flores de corte. Sustratos, manejo del clima, automatización y control en sistemas de cultivo sin suelo. Universidad Nacional de Colombia, Bogota 2011:79-108.

3. Gruda N. Do soilless culture systems have an influence on product quality of vegetables? J Appl Bot Food Qual 2009;82:141-7.

4. Voogt W, Sonneveld C. Nutrient management in closed growing systems for greenhouse production. Plant production in closed ecosystems. Berlin: Springer; 1997.

5. Beninni Y, Takahashi W, Neves S, et al. Teor de nitrato em alface cultivada em sistemas hidropônico e convencional. Hortic Bras 2002;20:183-6.

6. Guadagnin S, Rath S, Reyes F. Evaluation of the nitrate content in leaf vegetables produced through different agricultural systems. Food Addit Contam 2005;22:1203-8.

7. Santamaria P. Review. Nitrate in vegetables: Toxicity, content, intake and EC regulation. J Sci Food Agric 2006;86:10-7.

8. Conesa E, Niñirola D, Vicente M, et al. The influence of nitrate/ammonium ratio on yield quality and nitrate, oxalate and vitamin C content of baby leaf spinach and bladder campion plants grown in a floating system. Acta Hortic 2009;843:269-73.

9. Maynard D, Barker A. Regulation of nitrate accumulation in vegetables. Acta Hortic 1979;93:153-62.

10. Cárdenas-Navarro R, Adamowicz S, Robin P. Nitrate accumulation in plants: a role for water. J Exp Bot 1999;50:613-24.

11. Zhou ZY, Wang MJ, Wang JS. Nitrate and nitrite contamination in vegetables in
China. Food Rev Int 2007;16:61-76.

12. Neely HL, Koenig RT, Miles CA, et al. Diurnal fluctuation in tissue nitrate concentration of field-grown leafy greens at two latitudes. Hort Sci 2010;45:1815-8.

13. Proietti S, Moscatello S, Leccese A, et al. The effect of growing spinach (Spinacia oleracea L.) at two light intensities on the amounts of oxalate, ascorbate and nitrate in their leaves. J Hortic Sci Biotechnol 2004;79:606-9.

14. Cantliffe JD. Nitrate accumulation in spinach grown under different light intensities. Amer Soc Hort Sci J 1972;97:152-4.

15. Vieira IS, Vasconcelos EP, Monteiro AA. Nitrate accumulation, yield and leaf quality of turnip greens in response to nitrogen fertilisation. Nutr Cycl Agroecosys 1998;51:249-58.

16. Kaminishi A, Kita N. Seasonal change of nitrate and oxalate concentration in relation to the growth rate of spinach cultivars. Hort Sci 2006;41:1589-95.

17. Santamaria P, Elia A, Serio F, et al. A survey of nitrate and oxalate content in retail fresh vegetables. J Sci Food Agric 1999;79:1882-8.

18. Fonteno WC, Harden CT. Procedures for determining physical properties of horticultural substrates using the NCSU Porometer. North Carolina State University: Horticultural Substrates Laboratory; 2003.

19. Prazeres AO. Comparação de metodologias laboratoriais para determinação de azoto nítrico e amoniacal em solos e águas. Programa e Livro de Resumos do $1^{\circ}$ Congresso Nacional e Rega e Drenagem. Beja, Portugal. 2005;59-60.

20. Lastra OC. Derivate spectrophotometric determination of nitrate in plant tissue. $\mathrm{J}$ AOAC Intl 2003;86:1001-5.

21. Marschner H. Mineral nutrition of higher plants. $2^{\text {nd }}$ ed. New York: Academic; 2012.

22. Gougoulias N, Giurgiulescu L, Kalfountzos D, et al. Coir employed as soilless cultivation substrate and its interference with nutrient solution during two tomatoes periods (case study). Studia UBB Chemia 2015;2:177-85.

23. Prasad M. Nitrogen fixation of various material from a number of European countries by three nitrogen fixation tests. Acta Hortic 1997;450:353-62.

24. Handreck KA. Rapid assessment of the rate of nitrogen immobilization in inorganic components of potting media: I. Method development. Comm Soil Sci Plant Anal 1992;23:201-15.

25. Cresswell GC. Coir dust-A viable alternative to peat? Biol Chem Inst, Rydalmere, Australia 1992.

26. Merhaut D, Newman J. Effects of substrate type on plant growth and nitrate leaching in cut flower production of oriental lily. Hort Sci 2005;40:2135-7.

27. Canali S, Montemurro F, Tittarelli F, et al. Is possible to reduce nitrogen fertilization in processing spinach? J Plant Nutr 2011;34:534-46.

28. Canali S, Diacono M, Ciaccia C, et al. Alternative strategies for nitrogen fertilization of overwinter processing spinach (Spinacia oleracea L.) in Southern Italy. Eur J Agron 2014;54:47-53.

29. Netto AT, Campostrini E, de Oliveira JG, et al. Photosynthetic pigments, nitrogen, chlorophyll a fluorescence and SPAD-502 readings in coffee leaves. Sci Hortic 2005;104:199-209.

30. Liu YJ, Tong YP, Zhu YG, et al. Leaf chlorophyll readings as an indicator for spinach yield and nutritional quality with different nitrogen fertilizer applications. J Plant Nutr 2006;29:1207-17.

31. Hochmuth G, Maynard D, Vavrina C, et al. Plant tissue analysis and interpretation for vegetable crops in Florida. Coop Ext Serv Spec Ser SS-VEC. 1991.

32. Mills HA, Jones JR. Plant Analysis Handbook II. A practical sampling, preparation analysis and interpretation guide. Athens, GA: Micro Macro international, Inc.; 1996.

33. Siomos AS, Beis G, Papadopoulou PP, et al. Quality and composition of lettuce (cv. Plenty) grown in soil and soillless culture. Acta Hortic 2001;548:445-9.

34. Gruda N. Impact of environmental factors on product quality of greenhouse vegetables for fresh consumption. Crit Rev Plant Sci 2005;24:227-47. 